\title{
The development of education for sustainable development. Materials for inclusive education in South African curriculum settings
}

\begin{abstract}
From an opening standpoint that inclusion implies previous exclusions, this paper reviews the slow emergence of inclusive processes of Education for Sustainable Development (ESD) in the South African education system. It explores how the historical colonising process and modernist trajectories in the emerging nation state were exclusive and driven by interventionist forms of education while there was an uneven provision of education by race and for learners with disabilities. Today, national provision for special needs is being mainstreamed in new policies of inclusive education, shaping education provision with a broader inclusivity agenda. An emerging and more inclusive landscape for ESD is explored as co-engaged processes of transformation as an inclusive engagement of citizens intent on constituting the futures they want through deliberative processes of learning-led change. Here inclusive processes of social cohesion are strengthened and empowerment is promoted. The article reports two cases of learning materials for more inclusive ESD in South Africa. It describes how the broad scope of ESD and inclusion in South Africa developed around redress following the cultural exclusions of colonial history and the need for social cohesion as intervention-led processes for effecting social change.
\end{abstract}

Keywords: Inclusion, education for sustainable Development, South Africa, social cohesion, indigenous knowledge

\section{Zusammenfassung}

Unter dem einleitenden Gesichtspunkt, dass Inkusion eine vorhergehende Exklusion impliziert, wird die langsam voranschreitende Entwicklung der Integration einer inklusiven Bildung für nachhaltige Entwickung (BNE) im südafrikanischen Bildungssystem aufgezeigt. Es wird untersucht, inwiefern der historische Kolonialisierungsprozess und die modernistischen Entwicklungen im aufstrebenden Nationalstaat von interventionistischen Bildungsformen beeinflusst wurden, während es ein ungleiches Bildungsangebot je nach Hautfarbe und für
Lernende mit Beeinträchtigungen gab. Heute werden in Südafrika besondere Bedarfe von Lerndenden als Querschnittsthema in der neuen Politik für inklusive Bildung berücksichtigt und Bildungsangebote mit einem umfassenderen Anspruch an Inklusion gestaltet. Eine neue und inklusivere Bildungslandschaft für BNE wird als kooperativer Transformationsprozess untersucht - als inklusives Engagement der Bürger/-innen, die beabsichtigen, die Zukunft, die sie wollen, durch deliberative Prozesse des lernenden Wandels zu gestalten. Hier werden integrative Prozesse des sozialen Zusammenhalts gestärkt und Empowerment gefördert. Der Artikel stellt zwei Fallstudien der Entwicklung von Lernmaterialien einer inklusiveren BNE dar. Er zeigt auf, wie sich der breite Anwendungsbereich einer BNE und Inklusion in Südafrika aufgrund von Abhilfemaßnahmen entwickelt hat, die die kulturellen Ausgrenzungen der Kolonialgeschichte und die Notwendigkeit des sozialen Zusammenhalts als interventionsgesteuerte Prozesse zur Herbeiführung sozialen Wandels berücksichtigen.

Schlüsselworte: Bildung für nach haltige Entwicklung, Inklusive Bildung, Inklusive BNE, Vielfalt, Umgang mit Komplexität

\section{Background}

The idea of inclusion in education conveys a sense of change where something excluded or omitted is now being included in the system. From this standpoint the idea of inclusive education in South Africa has a unique character with the advent of a single, inclusive education system with the overturning of the Apartheid system of separate education in the early 1990s. The inclusive education system that developed from 1994 was the outcome of a long struggle to overcome the differentiating exclusions of colonial and Apartheid education from the 1800 s.

Within a colonial system differentiated by ethnicity, little state provision was initially made for students with disabilities. Patterns of differentiated educational provision, particularly for students with impaired sight and hearing were first 
apparent in early mission schools during the colonial era. Early special education provision was thus very uneven across the emergence of racially differentiated state schooling. Provision for special needs was mainly undertaken by a wide array of religious and volunteer organisations as one still finds today. The state did, however, successively make provision for specialist facilities especially for the physically disabled as well as for children who were hearing and sight impaired. ${ }^{1}$ This meant that across the school system, children with special needs in poorer areas, even today, are either integrated in some form of mainstream schooling, civic organisations or stayed at home in the villages and are supported by social grants. Exclusionary processes in the colonial and the Apartheid system have thus been superseded a policy of mainstreaming inclusion that we find on paper today. In reality, however, provision is uneven and state institutions provide a complex backdrop to the expansion of inclusive approaches to teaching and learning that are emerging alondside Education for Sustainable Development (ESD) across the current systems of educational provision in the southern African region.

\section{Historical Processes of Exclusion and the Struggle for Inclusion in Education}

Colonial modernity in South Africa was characterised by exclusionary cultural processes of erasure, appropriation, socio-economic marginalisation and recent mainstreaming patterns of inclusion alongside ESD. At a macro scale the early politics of the day was tipped against political inclusion although this was proposed in the Cape province for an emerging black elite. The opposite emerged at the same time in the other two provinces. Friedman (1975) reports how Bishop Merriman wrote to Jan Smutts on the two opposing views in relation to an inclusive franchise. Jan Smutts was the Prime Minister of the emerging colonial Union of South Africa after the earlier Native Rebellions and at the reconcillion after the Boer War. Merriman wrote:

"One is the Cape policy of recognizing the right to the franchise irrespective of colour of all who qualify [...]. The second is that adopted by the two republics and Natal, viz. the total disenfranchisement of the Native. What promise of permanency does this give? What promise of the future does it hold out? These people are numerous and increasing both in wealth and in numbers $[\ldots]$. They are the workers and history tells us that the future is to the workers." (p. 18)

In reply to Merriman Jan Smutts wrote:

"With much that you say I most cordially agree [...]. I sympathise profoundly with the Native races of South Africa whose land it was long before we came here to force a policy of dispossession on them [...]. But I don't believe in politics for them. Perhaps at bottom I do not believe in politics at all as a means for the attainment of the highest ends but certainly as far as the natives are concerned politics will to my mind only have an unsettling influence. I would therefore not give them the franchise, which in any case would not affect more than a negligible number of them at present." (p. 18-19)
Against this inscribed process of colonial exclusion it is notable how early colonial schooling was in a foreign language intended to rescue students from the mystical attributes of their primitive cultures through induction into the Christian faith and the civilised ways of The West. In early anthropological research, for example, an irrationality in indigenous peoples (natives) was ascribed to "magic conceptions of nature" as an obstacle to learning European ways (Junod, 1920). Here the underlying assumption in colonial dominion through education was that:

"Whatever the future may be, there is no doubt that for the present the white race has to rule and guide the black race.” (Junod, 1920, p. 76)

Here the colonial enlightenment supposition was that:

"Education, scientific training, higher moral and religious conceptions have delivered most of the Europeans from magic. The same will certainly happen to the Bantus if they submit themselves to the teaching brought to them by us, and there is no doubt that there is amongst them an ever-growing desire of obtaining instruction." (Junod, 1920, p. 85)

There were some notable exceptions like the earlier more inclusionary approach that emerged at the mission station in Colenso, for example. Edgecombe (1982) documents how students learned in Mother Tongue in more inclusive ways than elsewhere. These approaches eventually contributed to Bishop Colenso being excommunicated by the Mother Church in Britain for heresy and "going native" as he began to find merit in Nguni cosmology, particularly in relation to the story of creation. The struggles for inclusive education across colonial and Apartheid history have many examples of enlightened transitioning to more inclusive approaches to education but these seldom developed on any scale until the advent of an inclusive political system in 1994.

Shava (2008) documents how, over this imperial period of colonial ferment, the institutional sciences came into an ascendency in state institutions and much in the prevailing indigenous knowledge practices was appropriated to inform the rapidly growing disciplines of scientific endeavour. He probes how scientific institutions appropriated indigenous knowledge into the Western Canons, and Odora-Hoppers (2002) illustrates how today much of the intergenerational knowledge in the current school subject disciplines is not recognised by students as having been derived from the knowledge practices of indigenous people. For example, many of the health properties of Rooibos tea as a herbal infusion had been mapped out by the Khoi peoples of the Cape Fynbos Region. These were taken up as a caffeine-free health infusion by Western multi-national health industries. In recent history the roots of this knowledge were acknowledged with the reversal of a copyrighting of "Rooibos" in the USA. Another interesting example of colonial and modernist exclusion is how the ecological relation between the African Honey guide and indigenous people in the local gathering for honey was reduced to myth. The history of abjection is now under correction with the reinsertion of African heritage and knowledge practices to enhance inclusive relevance in the education system and the curricula of the region. ${ }^{2}$ 
After the early paternalism of an exclusionary colonial system of forced cultural induction and English language literacy, the Apartheid system of racially segregated education in Mother Tongue with Afrikaans and English developed. An attempt to introduce Afrikaans as the language of instruction in schools sparked the 1976 student uprising that started in Soweto and is commemorated as an iconic turning point into a national struggle for an inclusive education that would be free from the inscriptive divisions of Apartheid. With the overturning of the Apartheid system came inclusionary change but the struggle to effect quality education for all was centred on surface inscriptions of inclusive education for all. The question of inclusion was seldom read against historical patterns of intervention to give effect to change behaviour through education that characterised modern education in the $20^{\text {th }}$ Century.

\section{The exclusionary dimension in ESD as social intervention}

Intrenched dimensions of the sustained paternalism and exclusionary culture of colonial modernism, outlined above, prevailed with the hand of liberation intent on charting a new inclusionary path within an outcomes-based education system after 1994 (O’Donoghue, 2007). A deepening of inclusionary perspective had been notable in Environmental Education (EE) as sustainability concerns were integrated as cross-cutting matters in the new outcomes-based education (OBE) policies. O'Donoghue (2007) also notes how more inclusive approaches to EE emerged around imperatives to effect a transformative social solidarity through more participatory approaches to environment and sustainability education. In contrast to $\mathrm{EE}$ in the Global North, South African approaches reflect an early transitioning from nature study in natural areas to the inclusion of socio-economic and political concerns within an expanding scope that not only included social justice but also developed as an inclusive learning process of deliberative social cohesion. This emerged alongside and contrasted with the colonial institutional legacy of educational interventions notable in the programmes of most environmental organisations and state or- gans. Here an underlying paternalism retained EE/ESD as interventions to effect behavioural change but signalled the need for more participatory approaches.

Trangressing this underlying perspective of instrumental perspectives on ESD, Chikamori, Tanimura \& Ueno (2019) argue for ESD as an inclusive learning journey of reflexive critical change. They note that ESD "insists on a version of SD [Sustainable Development] that refers to our present actions, is aligned with the wellbeing of present and future generations, and is based on our understanding of, and learning from, past activities" (Chikamori et al., 2019, p. 1). Figure 1 reflects this Transformative Model of Education for Sustainable Development (TMESD) as a flowing interaction between retroductive learning emerging alongside and informing retrodictive analysis that impinges on learner decisions and action-taken in a present informed by the past and emergent in events going forward. Ojala (2013) emphasizes the need to consider emotion regulation strategies within ESD practices at individual, group and cultural levels. Further Ojala argues the importance "to be aware of emotion regulation strategies to promote pluralistic learning" (p. 3). Applying to Chikamori's TMESD, including indigenous knowledge in ESD practices opens up to learners emotions and identity and may, however, stimulate co-engaged learning and affiliation and therefore promotes inclusive learning processes.

The cultural and methodological shift in EE/ESD from processes of paternalistic intervention to inclusive processes of social solidarity and transformative social learning remains a long struggle (O’Donoghue, Kibuka-Sebitosi \& Tshiningayamwe, 2019). The landscape of educational inclusion in South Africa today is thus characterised by diverse and often contrasting perspectives on ESD. The Sustainable Development Goals (SDGs), as an agreed nation state agenda, include a complex array of interacting concerns with the necessary scope for contemplating societal action learning for transitioning to a more just and sustainable future world.

Despite this imperative, there is little direction on how the change anticipated and mapped out in the goals ought to be enacted. Education work with the SDGs (Education for

\section{A Schematic representation of TMESD processes}

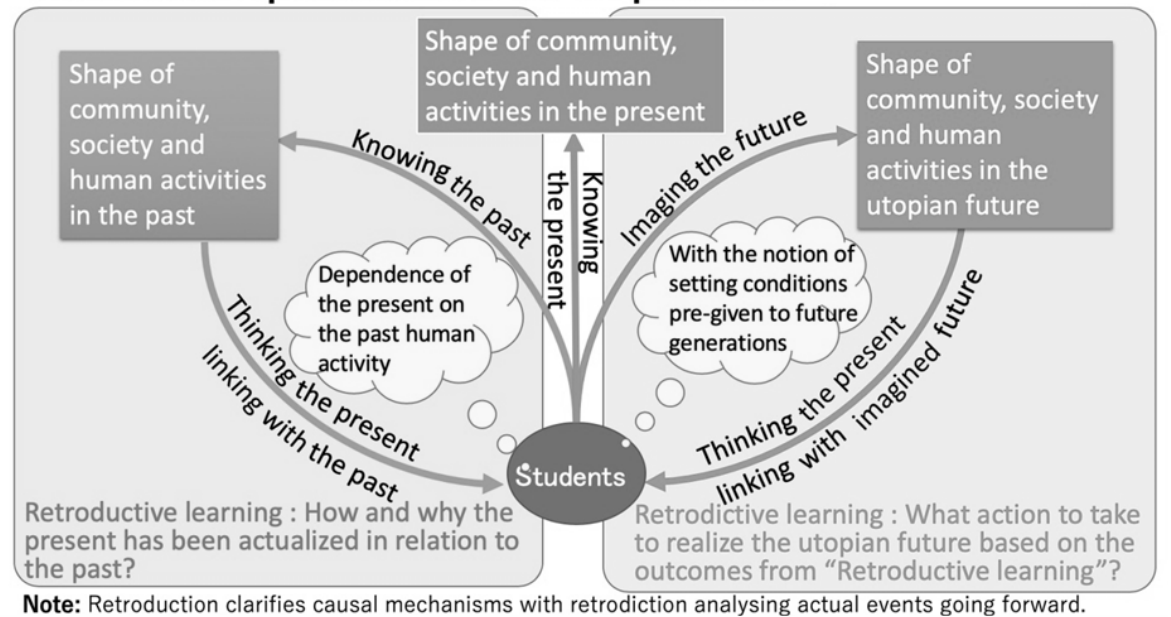

Fig. 1: Graphical representation of TMESD (Transformative Model of Education for Sustainable Development), Source: Chikamori et al., 2019 , p. 9 
Sustainable Development) is inscribed in SDG 4 as a transitioning process of global education that presents as inclusive societal processes of co-engaged learning and learner-led change. All of these concerns were deliberated in the framing of a research team to review ESD and inclusivity in the South African CAPS $^{3}$ curriculum with a view to the adaptive redevelopment of an inclusive education resource for use in teacher education and school curriculum settings in South Africa.

\section{Framing ESD Materials for the Landscape of Inclusion in South African Education}

Two ESD processes of materials development for inclusive education are reported below. Both were centred on teacher education but were designed for use by student and in-service teachers in more inclusive curriculum settings. The first produced exemplars for mainstreaming inclusion and focuses on special learning needs and the second was centred on the inclusion of indigenous knowledge practices in school curriculum settings.

\section{Global ESD Materials: "Cashew - A Global Learning Challenge"4}

The adaptive development of a cashew resource for South Africa involved a comparative policy review on inclusive education and an attempt to match the content with the requirements of the curriculum. The local materials were produced for teacher education and as a resource also for including special learning needs in mainstream classrooms. The cashew materials had been developed as an inclusive and multi-perspective educational resource for secondary schools so much of the resource had to be adapted for use in earlier years. ESD-relevant topics, such as politics, fair trade, climate change, world trade, natural sciences, history and cultivation have been captured around the cashew topic. The UNESCO competencies (Rieckmann, 2018) had also been integrated as cross-cutting through all the modules, such as system thinking, strategic competencies, critical thinking or self-awareness.

The cashew materials were intended to show how inclusion and ESD could be addressed through exploring the globalizing dimensions of the small cashew in schools in South Africa and elsewhere.

The resource notes how an inclusive curriculum rationale for school subject orientated, multidisciplinary learning processes resonates with competency perspectives in framing the cashew learning activities. These invite teachers and learners to work with and adapt the modules to begin to develop ESD competencies as capabilities for future sustainability. The modules provide educators with stimulating cognitive content, challenging social-emotional focus areas as well as practical learning-to-change actions towards future sustainability and social justice. The cashew material is presented as an adaptable resource for inclusive education and for the planning of diverse subject-centred curriculum programmes. The goal of the cashew material is the mainstreaming of inclusive education in ESD practices also by supporting activation of the socialemotional capabilities for assessing of the matters of concern and enable learner-led responses through a developing capabil- ity to act towards sustainability based on the individual learning abilities and a concern for the common good. Applying Klafki's (2007) constructivism approach, ESD helps the learners working with cashew materials to recognize what is known, assessing its felt importance and activating a creative capacity to act against the background of individual abilities and interests. This is consistent with the Past-to-Present (retroduction) and Present-to-Future (retrodiction) proposed by Chikamori et al. (2019) and discussed earlier in this paper. The inclusive approaches in the cashew material integrated Kullmann, Lütje-Klose \& Textor's (2014) principles of inclusive didactics based on Klafki (2007), namely:

- acceptance of all learners in their individuality,

- didactic integration of individual curricula,

- adaptions of learning content,

- adaptive teaching,

- co-teaching,

- cooperation of teachers and creating communities by cooperating with students.

The required didactical and methodological adaptions address learners with cognitive difficulties (complexity and cognition), deaf and hard of hearing and vision and perception. In concrete terms, this also means to differentiate learning contents, methods according to the learning needs, for example by learning with all senses, accessible language, in different settings of group world or action and more learner oriented. The intention here was the use of a variety of methods and for adaptions to help promote the participation of learners as well as increase the quality of teaching and learning. For learners requiring learning assistance, the following principles in lessons planning should be considered (Engagement Global \& bezev, 2017, p. 15):

- differentiation: time, methods/media, number of exercises, subject matter;

- reduction: quantity, clarity, objective;

- motivation: importance, relevance to everyday life, clarity, holistic learning;

- focus on action: promote active involvement, train activity planning, acceptance of responsibility;

- repetition/ritualisation: structure of content, space and time, interesting and motivating repetition, clear rules.

South Africa's own history and the experiences of other countries show that unity and social cohesion are necessary to meet social and economic objectives (NCP, 2013, p. 25). The cashew material was thus designed to foster a sense of social cohesion. The material was developed in the way that the didacticmethodological approaches towards the learning goals included a peace-oriented pedagogy, critical thinking, cooperative learning, participation, empowerment and dialogue. This approach implicates a strong inquiry-based learning focus and a transformative approach for learning settings and communities. The cashew material is thus intended to enable educators to foster resilience amongst the learners and to incorporate elements of critical reflection and dialogue with diverse identities and sense of belonging in diverse contexts: for example, in 
comparative and emerging identities in relation to cashew production and trade in Mexico, India, Germany and South Africa and the diverse contexts within these countries. By supporting teachers to avoid the reproduction of stereotypes, the cashew material contains methods for educators and learners to deal with stereotypes to foster social cohesion. The cashew material was developed within a broad concept of inclusion. For example, for the South African adaptation of the cashew material it was deliberately omitted to include all 11 national languages. Same challenge can be observed in including sign language materials for South African context.

South African Sign Language (SASL) is the official national language of the Deaf community in South Africa. While the grammar or syntax remains consistent, there are differences in the lexicon of SASL. These variations occur across the nine provinces, with further variations emerging within regions and schools. While all signs are recognised and acknowledged as being part of SASL and its rich and diverse heritage, "it would have been a somewhat onerous task to capture the content of the Cashew learning programme in a single signed presentation that would be spontaneously understood" (Engagement Global \& bezev, 2017, p. 17) for all deaf learners in South Africa.

\section{Hand-Print CARE and the Inclusion of Indigenous Knowledge}

The Hand-Print concept emerged as a proposition for learner-led action learning in the Centre for Environmental Education (CEE), Ahmedabad, India. Hand-Print CARE as an ethics-led action learning proposition was developed at a LOCUMS 5 research group meeting with Same (Sámi) educators in Alta, Norway. Here CARE emerged as an acronym reflecting an ethic of inclusive respect through Concern for others, being Attentive to needs, showing Respect for each other and being Engaged in learning actions for the common good. The inclusion of indigenous knowledge in learning became a key research trajectory in the materials development process. In a paper to explore the low school achievement of Indigenous Mother Tongue speakers, an analysis of the constitution of knowledge of natural processes indicated how concepts in the sciences were constituted as abstractions that bore little or no reference to the intergenerational knowledge practices of indigenous people in southern Africa (O'Donoghue et al., 2019). Science pedagogy was centred around the constituting of Pedagogical Content Knowledge (PCK) that took account of learner experience but not in a cultural historical sense that included intergenerational knowledge muted by colonial exclusions.

A key focus in the development of Hand-Print CARE materials ${ }^{6}$ became an imperative to include Indigenous Heritage Knowledge in ways that might enhance learning and relevance amongst indigenous learners learning the modern natural sciences related to the areas in which they are living. At the time there was an extreme drought that had the knock-on effects of:

- Water shortages:

What did indigenous people do in the past?

- Declining water quality:

How did they collect sweet water?

- Decreased food security:

What foods were used in times of drought?

- Reductions in nutrition

How has nutrition changed with the modern diet?

- Increasing health risk:

How were health risks managed in the past?

By asking the questions in brackets we worked with indigenous scholars to review historical patterns of response to drought, water quality, food security, nutrition and health practices to mobilise the intergenerational heritage knowledge that might provide relevant foundational learning for more inclusive ways of teaching the topic of climate change in Natural Science, Technology, Economic and Management Science and Life Skills. In summary, we found that the Xhosa, Hlubi and Pondo peoples had brought in and developed knowledge practices for

\section{Connecting Past and Present into Future in climate action case study materials?}
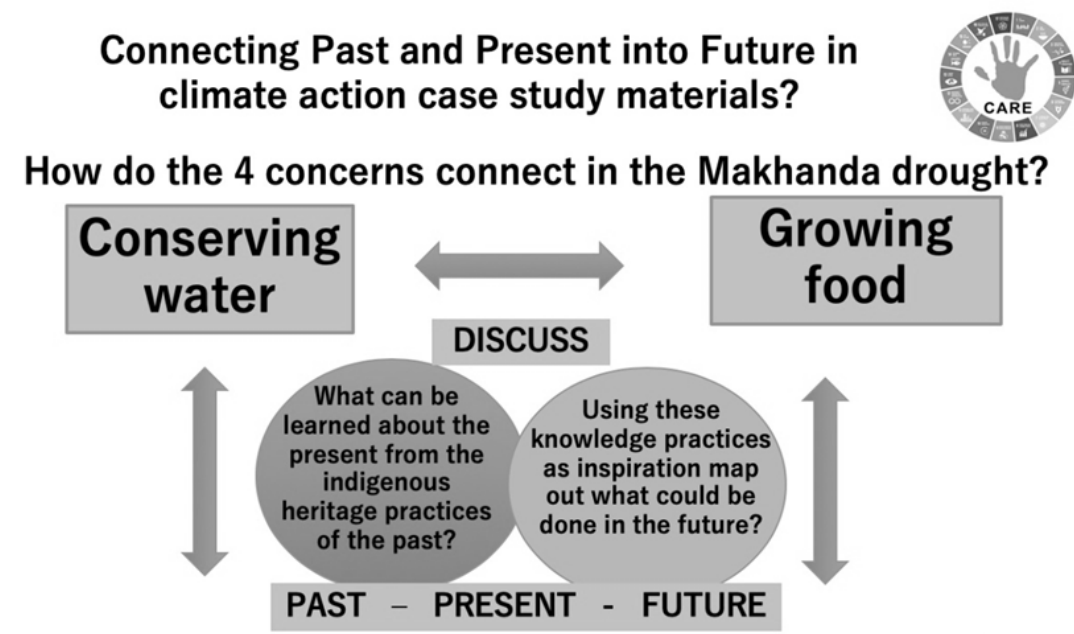

\section{Family Health}

\section{Family Nutrition}


coping with cycles of drought in the Eastern Cape. The extremes in the seasonal cycles were primarily driven by the el Niño-la Niña oscillation in the southern Pacific and the Botswana High Pressure System over the sub-continent in the winter season is now contributing to some of the increasing extremes of climate in the area.

The intergenerational knowledge uncovered and recovered through the research provided a rich foundation of heritage for engaging in social innovation to mitigate the effects of drought in the area. The foundational knowledge integrated in the Hand-Print CARE materials informed an expanded perspective on Topic-Specific Pedagogical Content Knowledge (TS PCK) and a Past-to-Present and Present-to-Future TMESD pedagogy reflected in Figure 2.

The climate extreme of drought in the area has produced low dams with knock-on effects of health risk, reduced food security, more costly clean water and decreasing nutrition that is deepining poverty in the area but this has not yet contributed to unrest and migration. Figure 2 is developed as an inquiry task to explore past responses to drought by indigenous peoples and the learning challenge of deploying this knowledge and what is known today in relation to the current problem of deepening drought exremes in the region.

The Topic Specific Pedagogical Content Knowledge in the Hand-Print CARE materials includes information on the following indigenous knowledge practices as foundational heritage for understanding science and imaging better ways of doing things together in response to climate change:

- Galesha (breaking the soil cap) to enhance water ingress into soil in anticipation of a delayed start to the summer rains.

- Uthuthu (ash flocculation) to clear springs and Amanzi mNandi (Zulu) water lifting to reduce bacterial loading.

- Combining umfuno (crops) with imifino (wild vegetables) in food gardening.

- Hand-washing when arriving home or greeting guests to keep disease at bay.
Seen together as cultural strategies in drought conditions it was possible to relate the Nguni cultural capital to technological responses to drought and scientific knowledge driving the mitigation of climate extremes in the region. This allowed us to develop a Climate Action Tool Kit for use in the Grade 7 Economics and Management Sciences. The kit also has activities that can be used in the Natural Sciences, Technology and Life Skills curriculum settings. The inclusion of Indigenous Heritage Practices in the Hand-Print CARE materials has opened up an educational response to the exclusions in colonial and modernist history.

\section{Concluding Synthesis and Discussion}

The southern African landscape of ESD and inclusive education cannot be reduced to teaching educators how best to mainstream learners with special needs. ESD has developed as an expansion in modern education to include the acquisition of the competencies and agency for learning to live in a changing world of and at risk. This is shaping change in learning and training environments (O’Donoghue, Taylor \& Venter, 2018) on a widening scale. Here cohesion and co-engaged and more inclusive modes of teaching and learning are emerging in school curriculum settings. The Cashew and Hand-Print CARE materials reflect the use of a competence approach and the use of the Sustainable Development Goals (SDGs) in open-ended learning progressions like TMESD that expand beyond conventional Teach-Task-Test routines of curriculum instruction. Figure 3 shows how the SDGs can be taken into deliberative work on climate change in the Eastern Cape of South Africa, informing an expansion of conventional learning progressions to include heritage and more learner-led inquiry. This extends to learner-led change challenge actions in Quadrants 2-4, reflecting an inclusive broadening of assessment for, in and of learning by participants (students and teachers). Integral to these modes of inclusive expansion in education is the need to training to include students with special needs as has been attempted with the cashews materials.
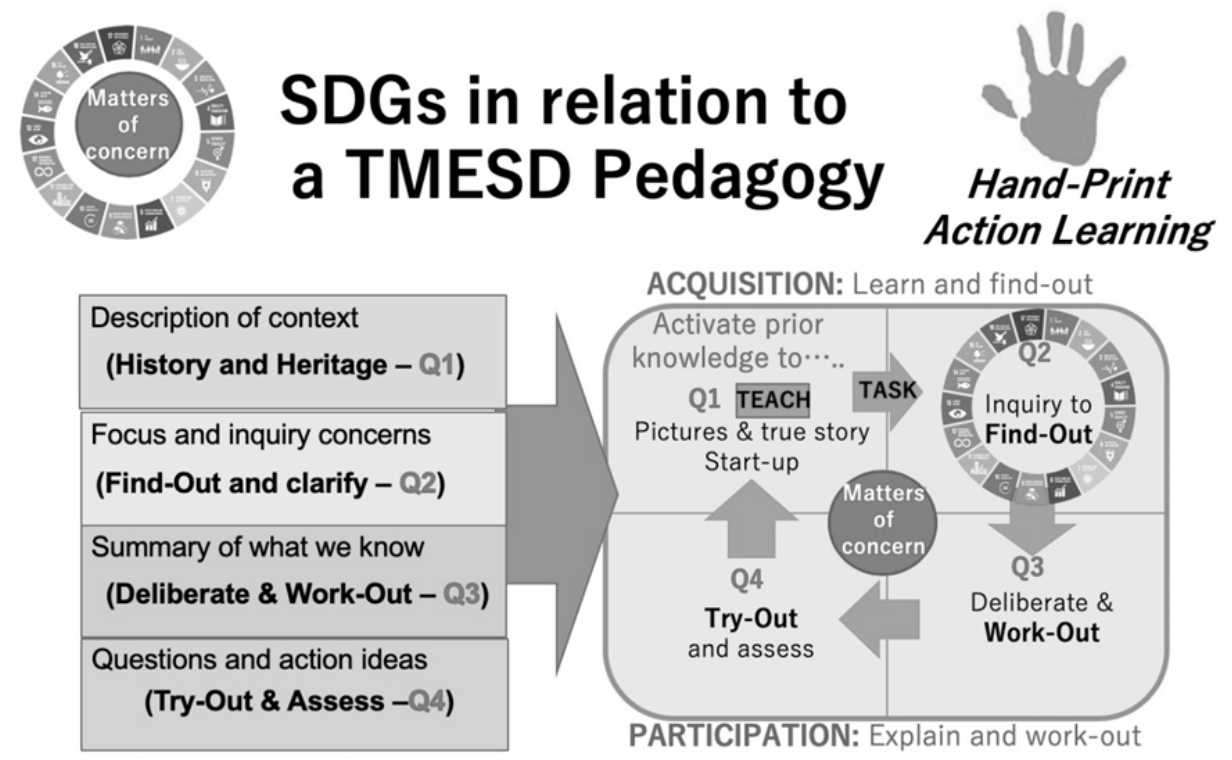

Fig. 3: Working with the SDGs into open-ended learning progressions in subject disciplines, Source: O'Donoghue (2020) 
Inclusive education has developed as an expanding and challenging education terrain, especially with the inclusion of ESD in the curriculum. Here it is not enough to make provision for an inclusive mainstreaming of students with special needs but there is a need to expand and reconceptualise the educational enterprise if we are to meet the challenges of cohesion and change necessary for constituting sustainable futures on a global scale. Following his recent sociological analysis of "Acceleration" in a modern world Rosa (2019) has begun to map out "A Sociology of our Relationship to the World" within which he notes: "Our relationships to the world are always both appetitive/affective and evaluative/cognitive, and I am convinced that the dynamic of life can essentially be understood as a constant oscellation between these two poles" (p. 135).

The prospect of these relations developing in ways that the search for relevance and future sustainability might be achieved will require many expansive shifts in education, not least of which are a reframing of the educational enterprise as cohesive processes of change borne of inclusive meaning making through ESD.

\section{Notes}

1 In most small towns and cities today one finds a mix of state and private organisations that make provision for special needs. In recent years state funding has been reduced amidst imperatives for inclusion and volunteer organisations are increasingly dependent on donations and support from private sector and corporate organisations, including National Lotteries.

2 In December 2019, Caleb Mandikonza of Wits University sent to Rob O'Donoghue an interesting set of curriculum review documents that are being produced through the Sustainability Starts with Teachers programme being coordinated through UNESCO, Harare. Access on 23.01.2020 http://www.unesco.org/new/en/mediaservices/single-view/news/sustainability_starts_with_teachers_esd_training_for_ southe

3 A National Curriculum and Assessment Policy Statement (CAPS)

4 A project team was convened to adaptively redevelop a ESD resource on Cashews that had been developed for inclusive education. The adaptive use of the materials was undertaken with the support of the German NGO bezev, the ESD Expert Net (South Africa, Germany, Mexico and India) and a small team of South African specialists in inclusive education for students with disabilities.

5 Local Culture for Understanding Mathematics and Science. Access on 23.01.2020 https://www.ntnu.edu/locums

6 See: https://www.handprint.in/handprint_care. Access on 23.01.2020

\section{References}

Chikamori, K., Tanimura, C. \& Ueno, M. (2019). Transformational model of education for sustainable development (TMESD) as a learning process of socialization. Journal of Critical Realism, 18(4), 420-436. https://doi.org/10.1080/147674 30.2019 .1667090

Edgecombe, R. (ed.) (1982). Bringing Forth Light: Five tracts on Bishop Colenso's Zulu mission, J.W. Colenso. Killie Campbell Africana Reprint. Pietermaritzburg: University of Natal Press.

Engagement Global \& bezev (2017). Cashew - a global learning challenge. Learning material for inclusive education. Bonn. Access on 23.01.2020 http://www.esd-expert. net/files/ESD-Expert/pdf/Was_wir_tun/Lehr-\%20und\%20Lernmaterialien/Cashe w_South\%20Africa.pdf
Friedman, B. (1975). Smuts A Reappraisal. New York: St. Martin's Press.

Junod, H. A. (1920). The Magic Conception of Nature Amongst Bantus. Reprinted from the South African Journal of Science Vol. xvii (p. 76-85). Johannesburg: Association for the Advancement of Science.

Klafki, W. (2007). Neue Studien zur Bildungstheorie und Didaktik. Zeitgemäße Allgemeinbildung und kritisch-konstruktive Didaktik. Weinheim: Beltz.

Kullmann, H., Lütje-Klose, B. \& Textor, A. (2014). Eine allgemeine Didaktik für inklusive Lerngruppen - 5 Leitprinzipien als Grundlage eines Bielefelder Ansatzes der inklusiven Didaktik. In B. Amrhein \& M. Dziak-Mahrer (eds.), Fachdidaktik inklusiv. Auf der Suche nach didaktischen Leitlinien für den Umgang mit Vielfalt in der Schule. LehrerInnenbildung gestalten, Vol. 3 (p. 89-107). Münster, New York, München \& Berlin: Waxmann.

National Planning Commission (2013). National Development Plan 2030: Our future, make it work. Pretoria, South Africa: Department of the Presidency.

O' Donoghue, R. (2007). Environment and Sustainability Education in a Changing South Africa: A critical historical analysis of outline schemes for defining and guiding learning interactions. Southern African Journal of Environmental Education, 24, $141-157$.

O’Donoghue, R. B., Taylor, R. J. \& Venter, V. (2018). How are Learning and Training Environments Transforming with ESD? In A. Leicht, J. Heiss \& W. J. Byun (eds.), Issues and Trends in Education for Sustainable Development (p. 111-131). UNESCO: Paris.

O’Donoghue, R., Kibuka-Sebitosi, E., Tshiningayamwe, S. \& Palmer, C. (2019). Navigating non-sense by exemplifying situated life experience and intergenerational heritage knowledge in ESD learning spaces. Southern African Journal of Environmental Education 35, 1-17. https://doi.org/10.4314/sajee.v35i1.8

O'Donoghue, R., (2020). Hand-Print CARE: A Teacher's Handbook. Environmental Learning Research Centre, Rhodes University.

Odora-Hoppers, C. (ed.) (2002). Indigenous Knowledge and the Integration of Knowledge Systems: Towards a philosophy of articulation. Cape Town: New Africa Books.

Ojala, M. (2013). Emotional Awareness: On the Importance of Including Emotional Aspects in Education for Sustainable Development (ESD). Journal of Education forSustainableDevelopment, 7(2),167-182.https://doi.org/10.1177\%2F097340821 4526488

Rieckmann, M. (2018). Learning to transform the world: key competencies in Education for Sustainable Development. In A. Leicht, J. Heiss \& W. J. Byun (eds.), Issues and Trends in Education for Sustainable Development (p. 39-59). UNESCO: Paris.

Rosa, H. (2019). Resonance: A Sociology of Our Relationship to the World. Cambridge: Polity Press.

Shava, S. (2008). Indigenous knowledges: a genealogy of representation and application in developing contexts of environmental education and development in southern Africa. Unpublished doctor of philosophy thesis, Rhodes University, Grahamstown, South Africa.

\section{Rob O'Donoghue}

is Professor Emeritus at the Environmental Learning Research Centre (ELRC), Rhodes University. In his research in environment and sustainability education, he has given close attention to indigenous knowledge practices and inclusive, action learning in post-colonial curriculum and community contexts. His most recent work on ethics-led transformative learning has been an ESD Expert-Net initiative on Handprint-CARE.

\section{Katarina Roncevic}

has more than 8 years experiences in ESD and inclusive education and has been working on whole-school approaches. Since 2019 she works for Greenpeace Germany in the education team and is a PhD Student at the University of Vechta. She is member of the international ESD Expert-Net. 